Post-print version: Marianne P. Ritsema van Eck, "Graffiti in medieval and early modern religious spaces: illicit or accepted practice? The case of the sacro monte at Varallo," Tijdschrift voor Geschiedenis 131, no. 1 (2018): 51-72.

\title{
[page. 51]
}

\section{Graffiti in medieval and early modern religious spaces: illicit or accepted practice?}

\section{The case of the sacro monte at Varallo}

\section{Marianne Ritsema van Eck}

\begin{abstract}
Graffiti in medieval and early modern religious spaces: illicit or accepted practice? The case of the sacro monte at Varallo

Leaving one's personal mark at a site of cult is an age-old practice attested in several religions, including Christianity from its earliest phases onwards. This article asks to what degree scratching graffiti into church walls was accepted behaviour in Western Europe during the medieval and early modern period. It seeks to complicate the view that disapproval of graffiti is a predominantly modern sentiment, by examining examples of both acceptance and resistance to graffiti at sacred sites. The attempts of Counter-Reformation bishop Carlo Bascapè (1550-1615) to root out what he perceived as impious vandalism at the sacro monte of Varallo in Northern Italy, combined with an analysis of the graffiti on the glass panes of the Ecce Homo chapel postdating Bascapè's ban, together serve to suggest new directions for the study of the pre-modern significance of, and particularly resistance to, graffiti.
\end{abstract}

Keywords: material culture, history of religion, graffiti, sacred space, sacro monte. 
[page 52]

Let the reader go to Varallo, for example, and note the names scratched up from the beginning of the sixteenth century to the present day, on the walls of the chapel containing the Crucifixion. [...] Why is it, I wonder, that these little bits of soul-fossil, as it were, touch us so much when we come across them? [...] few of us can see the lightest trifle scratched off casually and idly long ago, without liking it better than almost any great thing of the same, or ever so much earlier, done with purpose and intention that it should remain. ${ }^{1}$

The above response by the Victorian novelist and travel writer Samuel Butler (1835-1902) to the graffiti he encountered at Varallo and elsewhere in various chapels on his tour of Northern Italy contains telling assumptions about graffiti. Butler implies that graffitists leave behind a crucial piece of themselves, a soul-fossil, which is at the same time the product of a careless act done without the intention of leaving a permanent trace. This conception of graffiti as somehow unconscious expressions of a lower cultural register, which nonetheless preserve precious voices from the past, coincides with more generally held views in Butler's own day. ${ }^{2}$ The nineteenth century also first saw the application of graffiti as an illicit activity. ${ }^{3}$ There is a considerable body of evidence (which will receive attention below) that indeed suggests that writing on church walls was not necessarily considered an act of transgression, but was rather a condoned practice in many places throughout Western Europe during the medieval and early modern period.

The aim of this article is, on the one hand, to complicate the thesis of pre-modern acceptance of graffiti, by examining examples of disapproval of the same, and, on the other hand, to explore the particular significances of scribbling on the surfaces of sacred places. Medieval and early modern graffiti have received relatively little scholarly attention, a number of notable exceptions, such as the Norfolk Medieval Graffiti Survey, aside. ${ }^{4}$ The discussion below briefly reviews some major sites and corpora of graffiti that have been studied, paying particular attention to how graffiti may have been regarded: positively, neutrally, or negatively. Moreover, the social and devotional significances of leaving a mark in a religious space will be examined. Equipped with the interpretative frameworks that arise from this review, this article then turns to its chosen case study, namely the practice of, and institutional resistance to, graffiti at the sacro monte, or holy mountain, at Varallo in Piedmont (Italy) during the early modern period. 
[page 53]

\section{Graffiti at sacred locations: accepted practice?}

In order to come to grips with the significance of wall-scribbling in religious spaces, let us think back to Samuel Butler's appraisal of graffiti as precious yet unintentionally applied soulfossils. The idea of persons of bygone eras haphazardly leaving behind bits and pieces of themselves for us to examine may certainly appear attractive; however, it cannot hold true for graffiti at sacred locations, at the very least. A certain degree of intentionality is implicit in the nature of graffiti, because they are applied to a surface that was not originally intended to receive writing. On the basis of this, Véronique Plesch has cogently argued that applying a graffito to a surface constitutes a symbolic act of appropriation: laying claim to its location. ${ }^{5}$ Especially in the case of a religious location, we should certainly not assume that this was done carelessly, or without intention to remain visible. An important and ubiquitous phenomenon attested from the early phases of Christianity onwards are the graffiti left by pilgrims at sacred sites. ${ }^{6}$ These typically record personal names, because in this way pilgrims could leave behind a little piece of themselves, in order to maintain a small presence at the site of their devotion, even after their departure. ${ }^{7}$ Therefore, we may very aptly call a graffito at a sacred site a soulfossil, yet keeping in mind that it was most likely intentionally applied and emphatically meant to remain.

As we shall see below, recording a personalized presence on the wall of a religious space may also constitute a social act, joining a group of fellow devotees by means of a graffito, as well as a devotional act: a way of communicating with the divine. ${ }^{8}$ Whether or not these graffiti were then met with disapproval, as they often are nowadays, is a question that cannot be answered easily. Matters are complicated by the same obstacle that still to a degree hampers the study of medieval and early modern graffiti in general: neither comprehensive European surveys nor in-depth analyses of their significance exist. ${ }^{9}$ Therefore it is perhaps even more difficult to draw generalized conclusions about disapproval of graffiti in this period than it is with respect to the graffiti themselves, since cases of disapproval still need to be documented as much as do the graffiti themselves. Accordingly, the approach of this article is to document such a case of censure, following a brief review of the existing literature on pre-modern graffiti in England and Norway. The overview below is not designed to be exhaustive, but 
[page 54]

rather to provide a few points of departure for devising a solid approach for evaluating medieval and early modern attitudes towards graffiti. ${ }^{10}$ The case study of unwelcome graffiti at the sacro monte of Varallo that follows it aims to provide a starting point for additional research into the historically variegated reception of graffiti.

In comparison with other parts of Europe, English medieval graffiti have been subjected to a considerable amount of scholarly attention. In 1967 Violet Pritchard published a monograph on the subject, documenting and analysing a considerable corpus of graffiti found in the churches of several Eastern English counties. ${ }^{11}$ This study demonstrates not only how diverse and widespread these scratched geometrical designs, drawings, and writings were from the twelfth to the sixteenth century, but also emphasizes their (art)historical interest and value. Since then a number of papers on medieval graffiti, mostly work on single sites, have been published, and attempts at more systematic documentation and interpretation have been made. ${ }^{12}$ Recently, in 2010, the Norfolk Medieval Graffiti Survey was set up with the aim of producing a more comprehensive survey of graffiti in the United Kingdom. The director of this volunteer-based project, Matthew Champion, has published a monograph that offers an overview of all the different types of graffiti. He proposes that graffiti were 'both accepted and acceptable' to those in control of the church building, on the basis of apparent respect for graffiti during the medieval period, since they were not covered or removed. ${ }^{13}$

The thesis that graffiti did not carry any particular association with the forbidden during the medieval and early modern period has perhaps been most influentially voiced by Juliet Fleming. She convincingly argues that writing on walls "was not distinguished from other writing practices in early modern England, and not yet considered a vice'. In addition, Fleming interprets the sheer quantity of examples found in English churches as 'incontrovertible evidence that graffiti writing was once sanctioned in ways now foreign to ourselves'. ${ }^{14}$ However, this argument for institutional acquiescence in the practice of applying graffiti to church walls has its problems: there may well have been censure, even if it was popularly ignored by graffitists. Indeed, it is very hard to arrive at any sort of definitive conclusions about graffiti as either authorized or illicit writings in the absence of explicit bans or other types of documented disapproval or approval.

Two complementary, but in this particular respect disparate, evaluations of the graffiti in Norwegian stave churches illustrate this difficulty. In 1985 Martin Blindheim published a monograph about the graffiti in these characteristic wooden churches of the high middle ages (c. 1150-1250). ${ }^{15}$ Blindheim's project stands out on 
[page 55]

account of its scope as a survey, as well as because of its interpretative goal: a general reconstructive analysis of the circumstances under which the graffiti were applied. His take is comparable to that of Samuel Butler, in the sense that he sees the geometric shapes and designs, human figures, animals, ships, plants, coats of arms, weapons, and (runic) inscriptions as 'casual doodles', done without intention to remain for posterity. ${ }^{16}$ This is understandable if one looks, for example, at the attempts of a graffitist to carve pictures of lions in the stave church of Gol. ${ }^{17}$ However, despite the large number of such doodles in this and other stave churches, Blindheim unequivocally rejects the idea that people were freely allowed to make such carvings. Based on resemblances in the accomplished style of some of the drawings and their position, occasionally high up in the building, he concludes that the graffiti were done by travelling teams of specialist church builders during construction of the church. After consecration the scratching in the walls would stop entirely according to him, except for 'personal marks and occasional inscriptions'. ${ }^{18}$

Blindheim thus sees consecration, which turns the church into a markedly religious space, as an event that would in principle render leaving graffiti unacceptable. Recently, Annette Jones has offered a different perspective on stave church graffiti. Focused on inscriptions rather than drawings, her analysis emphasizes the striking suitability of these particular graffiti for a religious space, and concludes that 'the runic texts in stave churches were not illicit'. ${ }^{19}$ She rejects Blindheim's hypothesis about church builders as the main graffitists, and instead finds a gradual accumulation of graffiti over time, since most of the graffiti are located in parts of the building that would have been within reach of all. Apart from members of the congregation, including female ones, priests and travellers identify themselves too. The graffiti are suitable for the context of a church building because they constitute a religious statement, according to Jones. In line with the analysis of Plesch and Yasin, she holds that by writing one's name in the church one joined a particular socio-religious group, and at the same time sought a lasting personal connection with the divine. The fact that priests explicitly identify themselves in church graffiti may be taken as institutional acceptance of the practice. $^{20}$

An additional and telling example of priestly graffiti in a medieval Norwegian church can be found at Nidaros cathedral in Trondheim. Around the year 1300 the following graffito was carved into the stone of its interior: LAURENSIUS CELVI ANUS PETRI, ('Laurentius Kàlfsson is Peter's ass'). At the end of the thirteenth century Laurentius was a priest in the service of the bishop Jørund; Peter most likely is Peter of Husabø, a powerful supporter of 
bishop Jørund. On account of a quarrel between Jørund and the priests of the cathedral, Laurentius was sent to inform those priests that they had been excommunicated. The message was not received well, and they had Laurentius

\section{[page 56]}

flogged. This graffito thus represents a telling act of appropriation and self-assertion by the priests of this cathedral during a dispute with their bishop. ${ }^{21}$ Even if a little lewd, and seemingly inappropriate for the context, the cathedral priests deemed this graffito appropriate for their church, even though not all parties involved may have agreed. As the above examples from Norway illustrate, based on the surviving graffiti themselves, it is possible to find signs of both acceptance and rejection of graffiti.

Assumptions about medieval and early-modern attitudes regarding the either licit or illicit nature of graffiti can therefore only really be proven or disproven by documenting and investigating these historical reactions. Just as the study of historical graffiti was initially developed from specific case studies, the study of their historical reception must commence on the same level. In addition, such an endeavour requires different types of sources other than graffiti alone, although these of course remain important. Where should we look? In the case of personal attitudes, letters, diaries, and especially travel accounts may have something to offer (a discerning traveller, like Samuel Butler, is perhaps more likely to notice and react to a graffito than is a local who accepts it as a fixed and unremarkable part of his/her surroundings). However, in order to be able to draw more general conclusions, and engage with categories such as 'legitimate' or 'illicit' in a meaningful way, institutionalized reactions and attitudes are pivotal: regulations, (records of) punishment for the offence, or alternatively their prevailing absence must be explored.

In the case of religious spaces, the particular focus of this article, it therefore makes sense to consider ecclesiastical regulations on the topic, which may indeed differ quite substantially from one place or region to another. The assumption that, if there are many graffiti to be found at a church, applying them must have been allowed, may thus in some cases be nuanced. For example, in two cases ordonnantieborden, typical of early modern Dutch contexts, suggest institutional disapproval. These wooden plaques were hung in the church to encourage proper behaviour within its precincts, by listing transgressions and the associated fines. The ordonnantiebord of 1594 at the church at Enkhuizen stipulates that it is forbidden to write on the church's walls or columns with chalk, charcoal, or other materials, and to carve in the benches or woodwork. ${ }^{22}$ At Schermerhorn the ordonantiebord of 1659 likewise advertises 
a fine for chalking on the inside or outside of the church, and orders pocket knives to be kept away from 'the rood screen, pulpit,

[page 57]

pillars, doors, benches, or any other wood work' ${ }^{23}$ These regulations suggest that, even if graffiti were common reality, they were perhaps not universally appreciated.

\section{Graffiti at the sacro monte of Varallo}

In order to explore further the potential of examining pre-modern institutionalized disapproval of graffiti, this article will now consider the graffiti and their historical reception at the sacro monte, or 'holy mountain', of Varallo in Piedmont. This sanctuary was first founded in 1491 by the Franciscan friar Bernardino Caimi (1425-1499), and was intended to afford pilgrims who had no opportunity to travel overseas to the Holy Land a chance still to 'see Jerusalem' at Varallo. It did so by offering a parcours of freestanding chapels, distributed on a hill next to the town of Varallo, meant to evoke the Christian devotional topography of Jerusalem and other locations in the Holy Land. Starting out with just three chapels, the sacro monte soon grew to include twenty-eight chapels in 1514, and counts more than forty nowadays. Important locations include the chapels of Calvary and of the Holy Sepulchre, as well as the Bethlehem and Nazareth complex. ${ }^{24}$ After briefly considering graffiti in pre-modern religious contexts on the Italian peninsula, the remainder of this article will focus on graffiti at the sacro monte of Varallo. The anti-graffiti campaign run by Counter-Reformation bishop Carlo Bascapè (15501615) will receive particular attention, as will the possible functions of graffiti based on a case study of the graffiti on the windows of the Ecce Homo chapel.

From the earliest phases of the sacro monte of Varallo onwards the devout visitors to its devotional parcours were wont to leave graffiti in its chapels. These graffiti may broadly be understood as belonging to the phenomenon of pilgrimage graffiti, while also making up part of the context of Italic graffiti practices. ${ }^{25}$ It is pertinent to keep in mind that on the Italian peninsula the graffitist's writing slate would very often consist of mural paintings. In her work on late medieval graffiti in the chapel of St Sebastian in Arborio (Piedmont), Véronique Plesch draws attention to the importance of the receiving surface. She foregrounds the significance of etching writing into religious fresco images as a devotional interaction with that surface. Even if the graffiti at Arborio are predominantly a record of public events, iconic depictions of saints seem 
[page 58]

to have been the preferred location. ${ }^{26}$ As to whether graffiti were considered illicit writings, Plesch very tentatively observes that at the chapel of St Sebastian the practice went on for centuries, and is therefore likely to have enjoyed institutional toleration at least. ${ }^{27}$ Indeed, it is difficult to fathom the extent of acceptance or rejection in the absence of further documentation. As Arborio and Varallo are both situated on the Sesia River, with less than fifty kilometres separating them, they are part of the same regional context. Even if these sites and their graffiti are of a different nature, considering the question of illicitness at Varallo may help to contextualize cases such as that at Arborio.

Graffiti are omnipresent at the sacro monte of Varallo: some of the whitewashed (outer) walls of the chapels are covered with mostly modern graffiti in pencil. These are the modern witnesses of a tradition that has existed from the earliest phases of this sanctuary. Early examples are found for instance in the chapel of the crucifixion. ${ }^{28}$ The present configuration of this outstanding chapel was conceived by the artist Gaudenzio Ferrari (c.1471-1546). In the years 1517-21 he created a 3D crucifixion scene of life-sized terracotta sculptures surrounding a pre-existing wooden crucifix, set off against a background of mural paintings (figure 1). ${ }^{29}$ This configuration became an exemplary template for the other chapels. Nowadays [page 59]

visitors can admire the crucifixion scene only from behind a glass front; initially they could probably have moved more freely, getting quite close to the artwork, although quite soon, during the first half of the sixteenth century, some sort of fencing must have been added. Within this exceptional chapel the graffiti are found on the frescoed walls to the sides of the scene, where the arms of visitors could still reach. They usually consist of a date and a name, as pilgrimage graffiti typically do, in order to preserve a personalized trace of a fleeting presence at the sacred site. ${ }^{30}$ The graffitist's names testify not only to local Piedmontese visitors, but also record French, German, and even Spanish pilgrims. Gentile has noted a number of these graffiti, starting from the year 1521, and ending rather abruptly at the end of the sixteenth century. ${ }^{31}$ 


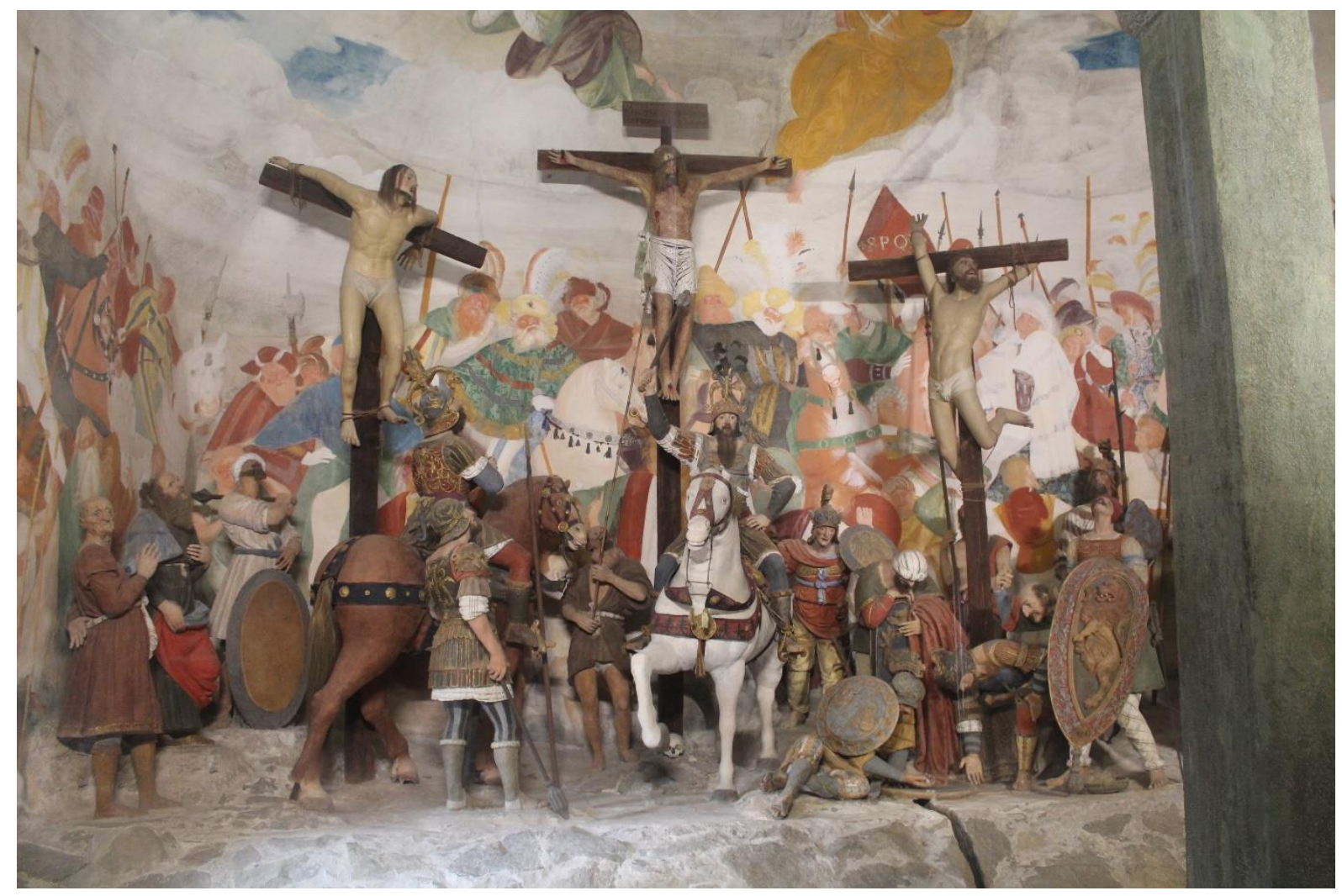

Figure 1: Interior of the crucifixion chapel by Gaudenzio Ferrari at the sacro monte of Varallo. Photograph by author.

This rather sudden end to the practice of applying graffiti at the chapel of the crucifixion is explained by Gentile with a succinct reference to a 1594 ban on graffiti at the sacro monte by Bishop Carlo Bascapè. ${ }^{32}$ It remains to be seen, however, whether the prohibition can sufficiently explain this abrupt break; other options (for example, a new viewing screen obstructing the application of graffiti), might also be considered. As will also become clear below, in the fourth section of this paper, graffiti certainly continued to be applied at other locations of the sacro monte. Before turning to discuss the examples of this at the Ecce Homo chapel, Bascapè's ban on graffiti will first be examined in more depth. In light of the thesis of pre-modern/pre-nineteenth century acceptance of graffiti, mentioned more than occasionally in the literature (see above), we might wonder whether Bascapè's initiative was perhaps exceptional. In the absence of comparable cases, this is hard to gauge, but it is certainly worthwhile to consider the following questions concerning this case of institutional disapproval of graffiti: what exactly did the prohibition comprise? What kind of understanding of graffiti does it imply? How was it broadcast? And how was it received? Was the ban, in short, a oneoff initiative by an eccentric individual, or did it find support? 


\section{Bascapè's 1594 ban on graffiti at the sacro monte}

On the 24th of February 1593 Carlo Bascapè was consecrated bishop of Novara. From this moment he became closely involved with the management of the sacro monte at Varallo. In a sense he had inherited it as a sort of showcase project from his illustrious predecessor and Counter-Reformation saint Carlo Borromeo (1538-1584), archbishop of Milan from 1564, who had shown great interest in the sanctuary. In the spirit of Borromeo, Bascapè strove to develop the sacro monte as a last alpine stronghold on the frontiers of Catholicism. ${ }^{33}$ His interventions were concerned with restructuring the layout of the sacro monte into a narrative of sacred history, the life of Christ in particular, correcting what he saw as its errors when compared

[page 60]

with the scriptures. In addition he aimed to turn the sanctuary into a pastoral instrument of the Tridentine reforms, shaping and controlling the religious experience of visitors as much as possible. ${ }^{34}$ In all respects Bascapè sought to maintain as tight a grip as possible on the management of the site.

On 24 September 1593 Bascapè made his first pastoral visit to the sacro monte in his new capacity of bishop, inspecting its chapels with great attention to detail: judging artistic value, noting apocryphal themes, and evaluating the visibility of the scenes displayed and the prescribed visiting order of the chapels. ${ }^{35}$ Exactly one year later, on 25 September, the bishop returned to discuss his plans with the Franciscan friars, civic dignitaries, and artists involved with the sanctuary. This time Bascapè not only wrote a report on his visit in Latin, but also issued a set of episcopal decrees in Italian. Apart from detailed instructions for modifying the material fabric of the sacro monte, both these texts contain explicit measures against graffiti. Bascapè was not the first bishop of Novara to object to graffiti at the sacro monte. His direct predecessor, Cesare Speciano, had already briefly noted the many inscriptiones in 1585, and had ordered them to be removed, thenceforth forbidding the writing of them. ${ }^{36}$ Bascapè, however, planned a much more developed anti-graffiti campaign. The Latin report of the 1594 pastoral visit stipulates that a prohibition in both Latin and Italian was to be advertised next to the entrance to the sanctuary, and again at the entrance to each chapel, stating:

By the order of the reverend Monseigneur the bishop of Novara on the 26th of November 1594: no one dare write on the walls, images, fences, doors, windows, columns, or other of this sacro monte, nor otherwise vandalize them (guastarle) on pain of the interdict of the Church, to be incurred immediately and surely (senz'altro), and 
[a fine of] four scudi, half [to be paid] to the workshop [of the sacro monte], and the other half to the accuser. ${ }^{37}$

From this ban it is apparent that Bascapè clearly interprets graffiti as vandalism, since it equates writing on the surfaces of the sanctuary as 'breaking them' (guastarle). Moreover, it establishes a relatively severe punishment: exclusion from (the efficacy of) the rites of the Catholic Church, as well as a monetary fine. In addition the 1594 decrees by Bascapè also

[page 61]

order that existing graffiti found on any surface are to be removed, and thus remind us of modern conservation practices, which often obliterate historical graffiti. Supervision at the sanctuary is instructed to keep everything 'clean', and to enforce the ban. ${ }^{38}$ Overall, these measures promoted by the bishop of Novara display sentiments about, and an understanding of, graffiti that is identical to modern disapproval.

Bascapè seems to have been bent on fighting fire with fire, judging from his instructions about how the prohibition should be broadcast at the sacro monte. The report on his visit already states that the text of the ban should be displayed on both columns of the entrance to the sacro monte, as well as at each chapel, in both Latin and Italian. The 1594 decrees by Bascapè further indicate that his prohibition was to be printed in Latin and Italian in big letters, and should always be affixed in a visible place at each chapel and near precious images, in order to prevent further damage. By making the ban on graffiti omnipresent at the sacro monte in the shape of a bilingual printed bill in big lettering, the bishop's instructions seem to have been geared towards replacing the informal, illicit writing (graffiti) at the sanctuary with a different type of writing. Bascapè's uniformly printed bill is an example of what Yasin has termed 'the steadfast voice of institutional authority', which in this particular case seems to have been designed to drown out the 'steady hum' of unorchestrated clusters of graffiti. ${ }^{39}$ Like the ordonantieborden at Enkhuizen and Schermerhorn (see above), this institutional voice against graffiti was advertised in writing at the same location where it was supposed to prevent illicit writing, thus competing for predominance in that same space.

The paper posters with Bascapè's ban could only represent the voice of institutional authority in the battle against graffiti for as long as they would last outdoors, and/or the management of the sanctuary kept reposting them. However, a more enduring visual example of the prohibition still survives at the chapel of the Temptation of Christ in the desert. This chapel was constructed around 1500 and previously displayed a wooden statue of Christ 
carrying the Cross to Calvary. In the 1570s the scene of the Temptation was added, which later, in 1599 , became the only scene in this chapel. ${ }^{40}$ Around the turn of the seventeenth century a fresco containing the text of the 1594 ban was painted above an exit door that is now closed off (figure 2). Why Bascapè's ban was made more enduringly present in this particular chapel is difficult to say with certainty, although quite possibly the chapel had attracted an above average amount of graffiti. ${ }^{41}$ The former facade of this often modified chapel, now the back wall, is covered in graffiti, some of them dating back to the early sixteenth century. ${ }^{42}$ The nineteenth century fresco that now frames the original prohibition

[page 62]

fresco also suggests that at that time the ancient ban was still relevant, and that a need was felt to reinforce it visually. The memento mori iconography — two allegorical figures, representing probably piety and penitence, and an hourglass and a skull — was very likely designed to remind visitors of the vanity of leaving graffiti. Contemporaneous painted notices found on several walls of the sacro monte politely implore the visitor not to write on its walls.

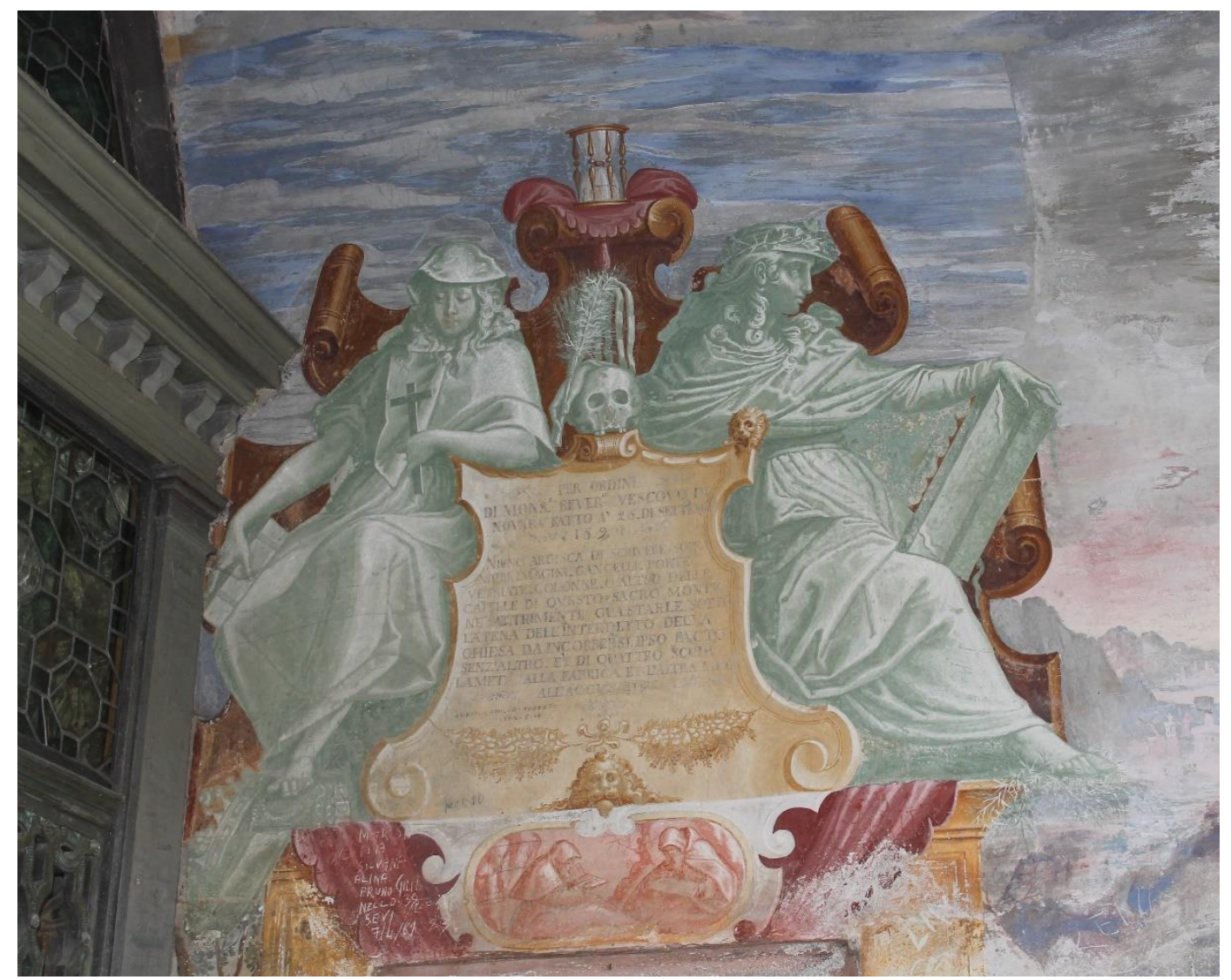

Figure 2: Fresco displaying the text of the 1594 ban on graffiti, above a former exit door at the chapel of the Temptation.

Photograph by author. 
Carlo Bascapè thus made an orchestrated effort at eradicating graffiti and the writing of it at the sacro monte of Varallo. The question remains whether Bascapè's rejection of graffiti should be interpreted as representative of his time and context, or rather be seen as an isolated case. Only fifty kilometres away, at the chapel of St Sebastian at Arborio, graffiti seem to have been tolerated. ${ }^{43}$ However, a possible explanation might be that this relatively modest peripheral chapel was less likely to attract the attention of zealous Counter-Reformation bishops on this score than was the much more prestigious sacro monte. Let us recall first of all that Bascapè's predecessor Speciano had already succinctly forbidden graffiti on the sacro monte ten years before, in 1585 .

\section{[page 63]}

Moreover, the 1594 ban enjoyed a generally positive reception, except perhaps by graffitists subject to its punishments. ${ }^{44}$ One year later, on 24 May 1595, the senate of the city of Milan issued a decree in support of Bascapè's initiative. It raised the original fine on applying graffiti at the sacro monte from 4 scudi to 25 , adding three lashes of the whip, and doubling the fine to 50 scudi for writing on an image. ${ }^{45}$

In addition contemporaneous publications on the sacro monte seem to have agree with Bascapè. For example, a guidebook by Bartolomeo Manino that describes four important Northern Italian sacri monti and was published in 1628 contains a poem 'against those who write on the pure white walls of the chapels'. It opens with a threatening quote from Exodus (31:14), and continues:
Ah, foolishness, reckless and daring hand,
That dare touch with vain writing
The sacred walls of the sovereign Mount.
You will feel double punishment, grave and hard,
Being caught suddenly or vainly:
Every price you will pay for your obscenity.
The Turk himself is better than you
Who in his own temple does not spit, whilst profaning all else. ${ }^{46}$

Manino thus maintains a very dim view of graffiti and its authors, who are apparently worse even than the Ottomans, represented here as the stereotypical evil and impious other. He is 
joined in this by Giovanni Battista Fassola. In 1671 Fassola published a monograph dedicated solely to the sacro monte of Varallo in which he profusely praises Bascapè's 'rigorous orders' against graffiti, and calls graffitists idioti ${ }^{47}$ In conclusion, we may observe that the scale and intensity of Bascapè's anti-graffiti campaign at the sacro monte of Varallo may have been exceptional, although this is hard to verify for want of analyses of comparable cases. Nevertheless, the sentiments about graffiti that his efforts imply appear to have been felt more generally.

It is hard to say precisely how success-

[page 64]

ful Bascapè's prohibition actually was, since its implementation and attempts to protect the spaces and objects of the sacro monte from graffiti remain to be documented fully. Overall, circumstances for its implementation seem to have been less than ideal. First, the Franciscan keepers as well as the civic patrons from Varallo were both dependant on financial donations from pilgrims for the management and upkeep of the sacro monte. Particularly in the case of a guided group visit for wealthy visitors, neither party would have been likely to correct graffitists among them. Second, from the second half of the sixteenth century onwards the Franciscans were in conflict with the civic patrons, the bishop siding with the latter group. ${ }^{48}$ Therefore we may infer that the willingness to actively support Bascapè's orders on preventing graffiti may have been limited on the part of the Franciscans. In addition to this, the sanctuary consists of a large hilly area with over forty individual chapels, often separated by quite considerable distances and winding paths. For good reasons, then, the text of Bascapè's ban stipulates that the 'accuser' (an observant third party, i.e. another visitor) is promised a financial reward for reporting transgressions. ${ }^{49}$ In short, while Bascapè's ban prohibits graffiti always and everywhere on the sacro monte and there are no sources that indicate any informal exceptions, it appears that patrolling and upholding the rules always and everywhere on the sacro monte would have been quite challenging. These difficulties may therefore have led to a practice of reluctant toleration of the continued writing of graffiti, simply for want of means to prevent it.

\section{The continued significance of graffiti at the Ecce Homo chapel}

Despite Bascapè's and later attempts to eliminate graffiti at the sacro monte of Varallo, visitors remained relatively free to leave behind a personal mark. Even though writing graffiti had acquired an aura of explicit illicitness from the late sixteenth century onwards, it had not lost 
it positive functions. Leaving a personal mark at this sacred location continued to be attractive to visitors to the sanctuary, in spite of the risk of being caught. The possible motivations for this have already briefly been mentioned above: entrusting a soul-fossil, a personalized trace, to the wall of a sacred site was often intended to maintain a more enduring presence there. In order to accomplish the second aim of this article - to explore further the particular significances of writing on the surfaces of sacred places - one particular cluster at the sacro monte of Varallo will now receive more detailed attention.

It concerns the graffiti on the glass panes of the viewing screen in front of the Ecce Homo chapel, which date mostly to the eighteenth century (figure 3). There are several reasons for studying this specific cluster of graffiti. First, it offers the opportunity to complicate suggestions about the effectiveness of the 1594 ban based, for example, on the graffiti in the crucifixion chapel. Second, the graffiti at the Ecce Homo chapel can also offer a novel perspective on how graffiti can serve as a historical source regarding the sacro

[page 65]

monte, in a different way than has previously been appreciated. Apart from providing information about the identity or nationality of visitors, for example, graffiti can also be analysed from a vantage point that highlights what the sacro monte as a pilgrimage destination meant to them. Moreover, while graffiti are omnipresent at the sacro monte of Varallo, they still need to be catalogued in an exhaustive corpus. Establishing corpora of graffiti is a prerequisite for any in-depth analysis. ${ }^{50}$ Therefore, in the absence of a larger corpus, it makes sense to base this preliminary exploration on a cluster that is coherent enough in terms of dating and content to be analysed by itself as a micro-corpus of graffiti. My analysis will be guided by the set of interpretative steps for analysing graffiti laid out by Plesch. After a methodical consideration of the what, where, how, when, and by whom of a corpus of graffiti, finally the more analytical why question may be answered. ${ }^{51}$ 


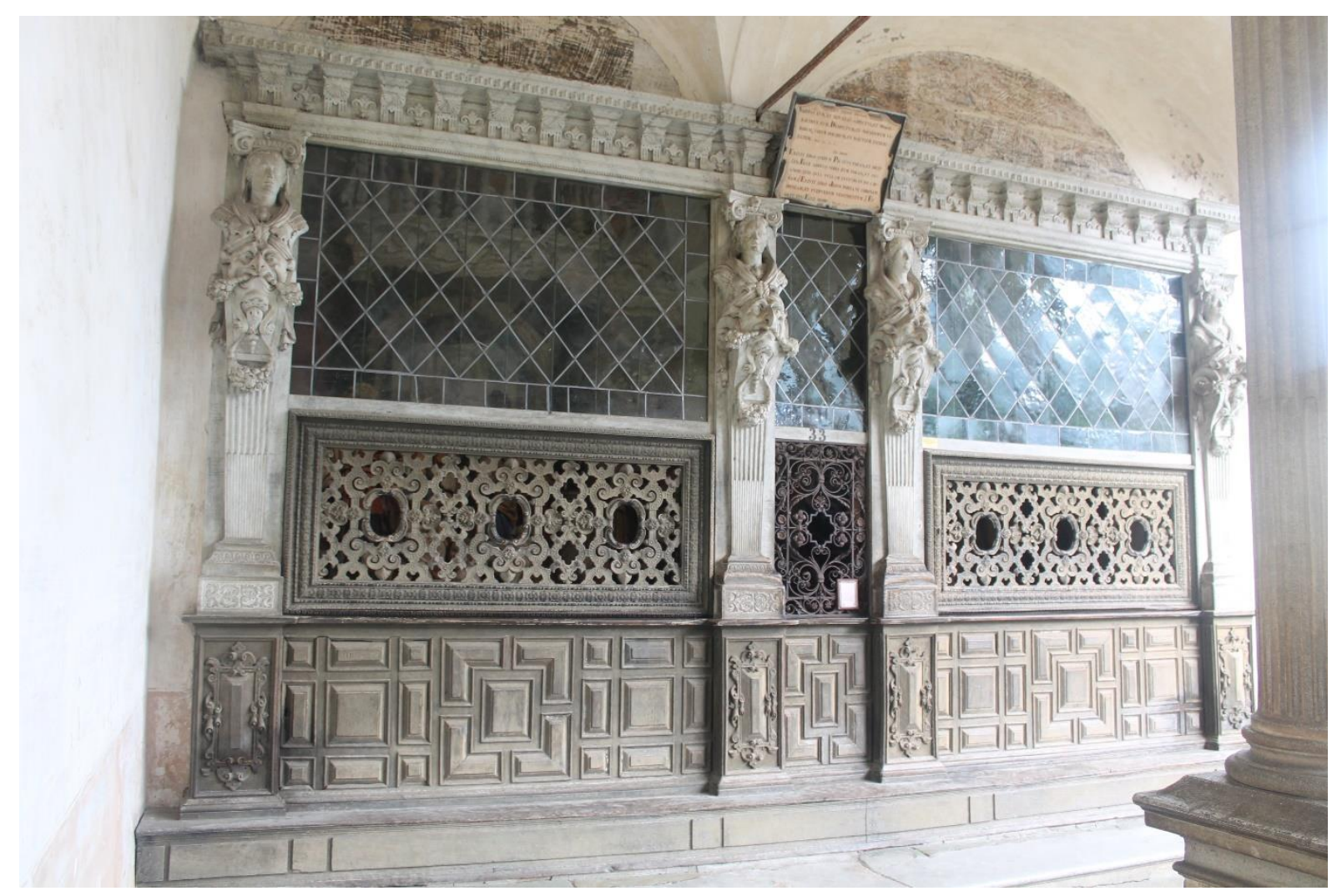

Figure 3: The viewing screen in front of the Ecce Homo chapel.

Photograph by author.

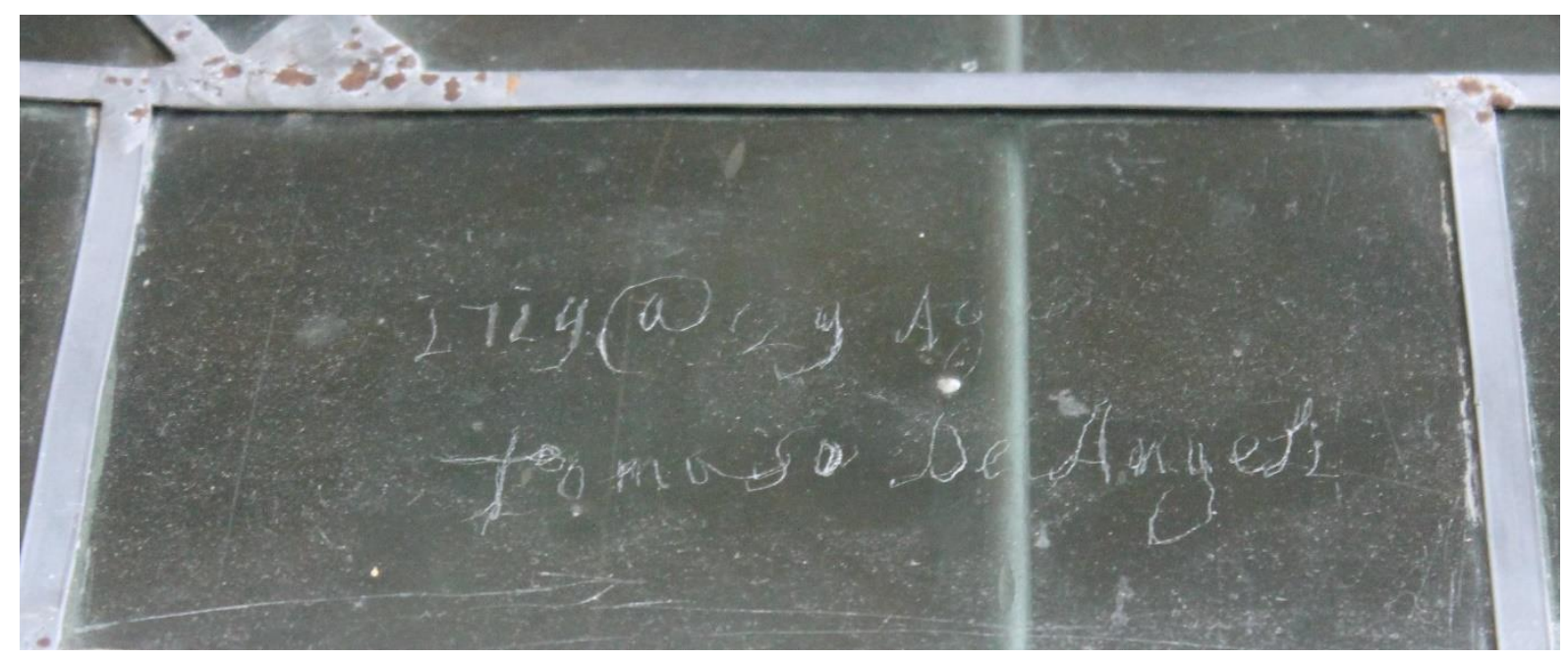

Figure 4: Graffito on windowpane of Ecce Homo chapel: '1719@ [ad] 29 Ago. Tomaso de Angeli'.

Photograph by author.

The first step is to establish the character of the graffiti at the Ecce Homo chapel: drawings (what do they represent) or writing (names, dates, events, prayers, etc.)? The present 
corpus contains only personal names and dates, often coupled, though partly illegible; for example: '1719 on 29 August, Tomaso de Angeli' (figure 4). ${ }^{52}$ With regard to when they were written, the majority of the dates recorded point to the eighteenth century, although the years 1568 and 1601 are also represented, as well as the nineteenth and twentieth century, both once. ${ }^{53}$ Additionally, the occasion of applying these graffiti can broadly be described as a pilgrimage to the sacro monte, and along the chapels that together represent a staging of salvation history. The method with which they were inscribed in the glass may be described as scratching or engraving, possibly with a diamond ring. ${ }^{54}$ Concerning the graffitists themselves, we might infer that their socio-economic standing must have been relatively substantial, in order to be able to afford to possess such a ring. The majority of the names are male. Husbands twice record the names of their wives, for example: ' 1730 [on] 3 June Carlo Bonazola with his wife Maria Antonia Bonazola'. ${ }^{55}$ Only once may the graffitist have been female, engraving the glass with 'Fortuna Cantino with her son Tomaso 1778 on 8 January'. ${ }^{56}$ Finally, it stands out that one particular family name, Cantino, is apparently overrepresented on the panes Ecce Homo chapel: it appears ten times on the nineteen panes containing graffiti.

With the basic facets of the what, when, how, and by whom questions tackled, the location of the graffiti may now be analysed. This is an essential aspect, since a defining feature of graffiti is that its surface was not originally meant to receive it, and may thus represent a

\section{[page 66]}

significant appropriation and/or repurposing of the surface. ${ }^{57}$ The graffiti in this particular case study are situated on the lower registers of panes of the screen at the Ecce Homo chapel, within arm's reach from the ground (figure 5). In order to fully comprehend the significance this location may have held for visitors of the sacro monte, including our graffitists, it is vital to assess how the Ecce Homo chapel

\section{[page 67]}

makes up part of the larger context of the sacro monte, a regionally as well as (inter)nationally popular pilgrimage destination. 


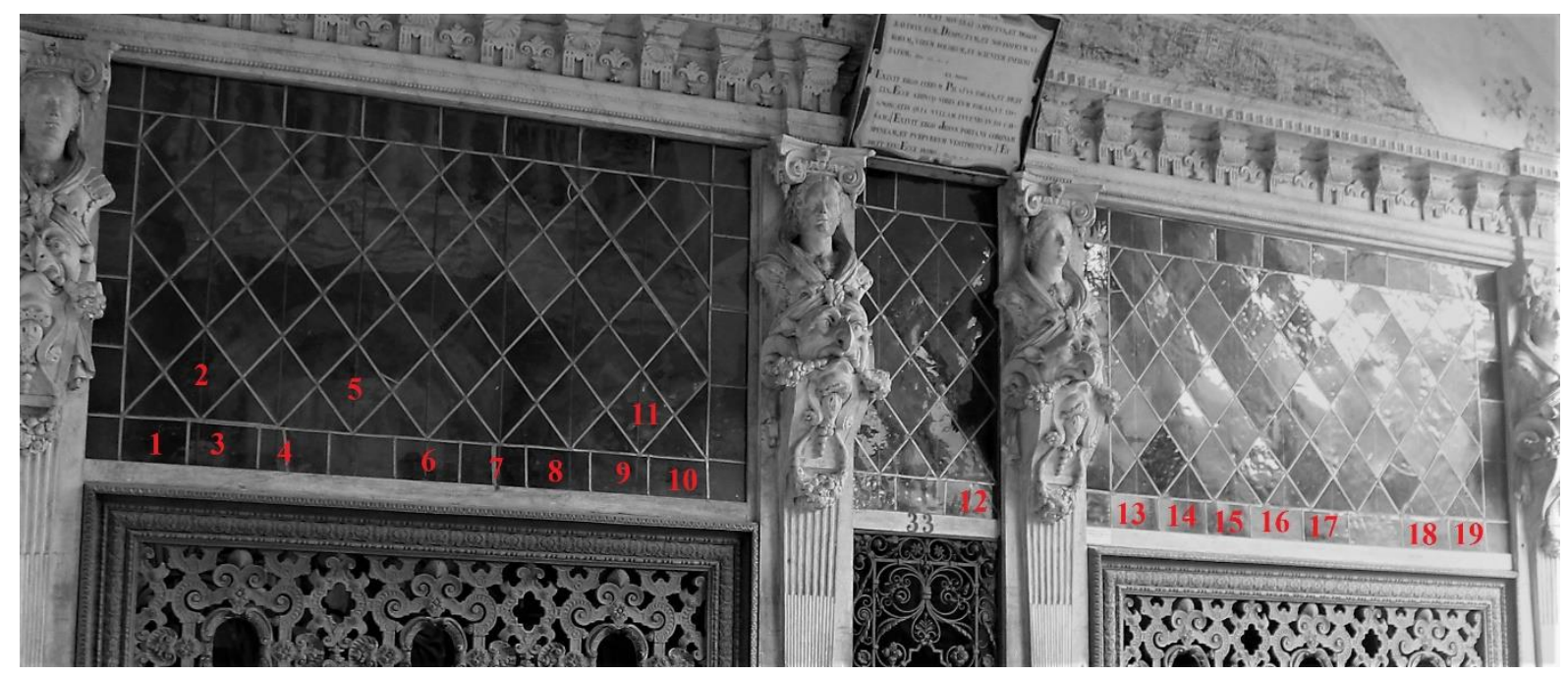

Figure 5: The position of the graffiti on the panes of the Ecce Homo chapel. The numbers refer to the numbering of the associated graffiti in the appendix.

Photograph by author.

The Ecce Homo chapel represents the well-known iconographic theme of Pilate presenting Christ, crowned with thorns, to a hostile crowd, speaking the words ecce homo: 'behold the man'. This chapel forms part of a larger structure at the sacro monte of Varallo that is sometimes referred to as the palace of Pilate. This building is very much the brainchild of Carlo Bascapè, and houses eight chapels that represent passion scenes set at Pilate's residence, such as the flagellation, the coronation with the crown of thorns, Ecce Homo, and Pilate washing his hands in innocence. The plan for this structure was first attested in connection to his pastoral visit to the sacro monte of 1602, and aimed at conforming the order and content of the chapels to biblical narrative as much as possible. Later, in 1607, Bascapè also ordered a made-to-scale replica of the Scala Sancta in Rome, believed to have originally formed part of Pilate's palace in Jerusalem, and to have been climbed by Christ during the passion (figure 6). ${ }^{58}$ At Varallo the visitor could thus compassionately identify with Christ: coming out of the dark indoor corridor housing the previous chapels (flagellation, coronation with crown of thorns, Christ climbing the steps), and the into the light, walking up the replica of these iconic steps him/herself, and finally meeting the Ecce Homo chapel at the top. 


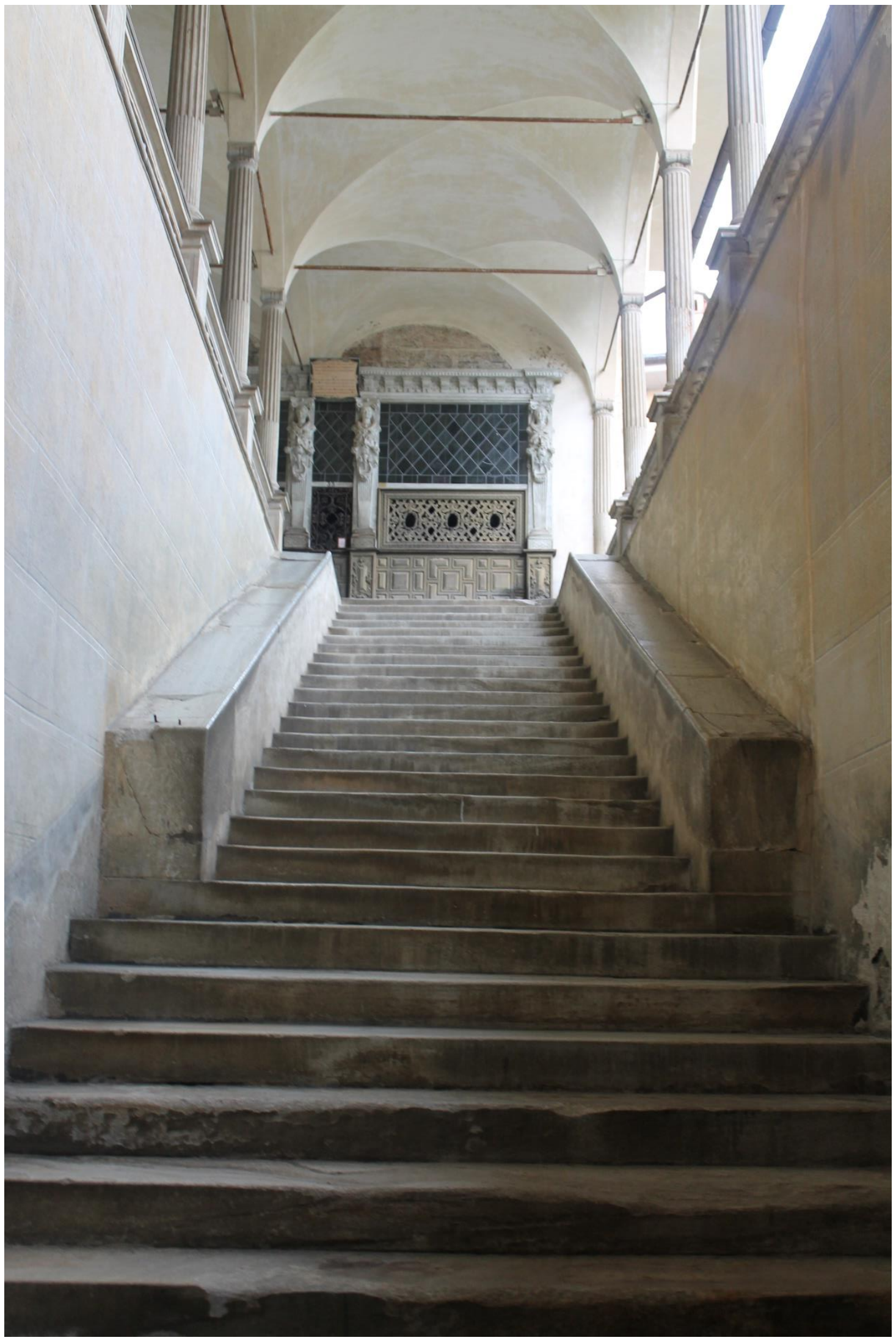

Figure 6: The replica of the Scala Sancta leading up to Ecce Homo at the sacro monte of Varallo.

Photograph by author. 
Peering through the screen of this chapel the visitor would then behold a space filled with terracotta statues against a background of frescoed walls, representing the Ecce Homo scene (figure 7). Bascapè was closely involved with orchestrating the impact of this scene. In 1608 he gave very detailed instructions, especially concerning the figures of Christ and Pilate: Christ should look completely flagellated and bloody, his face smudged, full of blood, spittle, and tears; Pilate, to his right, should be dressed in a 'Roman' outfit, and look compassionate. For the crowd below

[page 68]

the balcony with Christ and Pilate, Bascapè ordered, on the one hand, statues making angry gestures with distorted faces, and on the other hand, figures clearly focused on Christ, some weeping. ${ }^{59}$ This is a scene designed, in short, to help visitors to the sacro monte to identify with the passion as much as possible, and to elicit strong emotions of compassion for Christ at a crucial stage of his suffering. To write one's name on the glass panes of this chapel is to identify with a dramatic devotional peak in the parcours of the sacro

[page 69]

monte, heightened by the somatic experience of just having climbed the Scala Sancta replica.

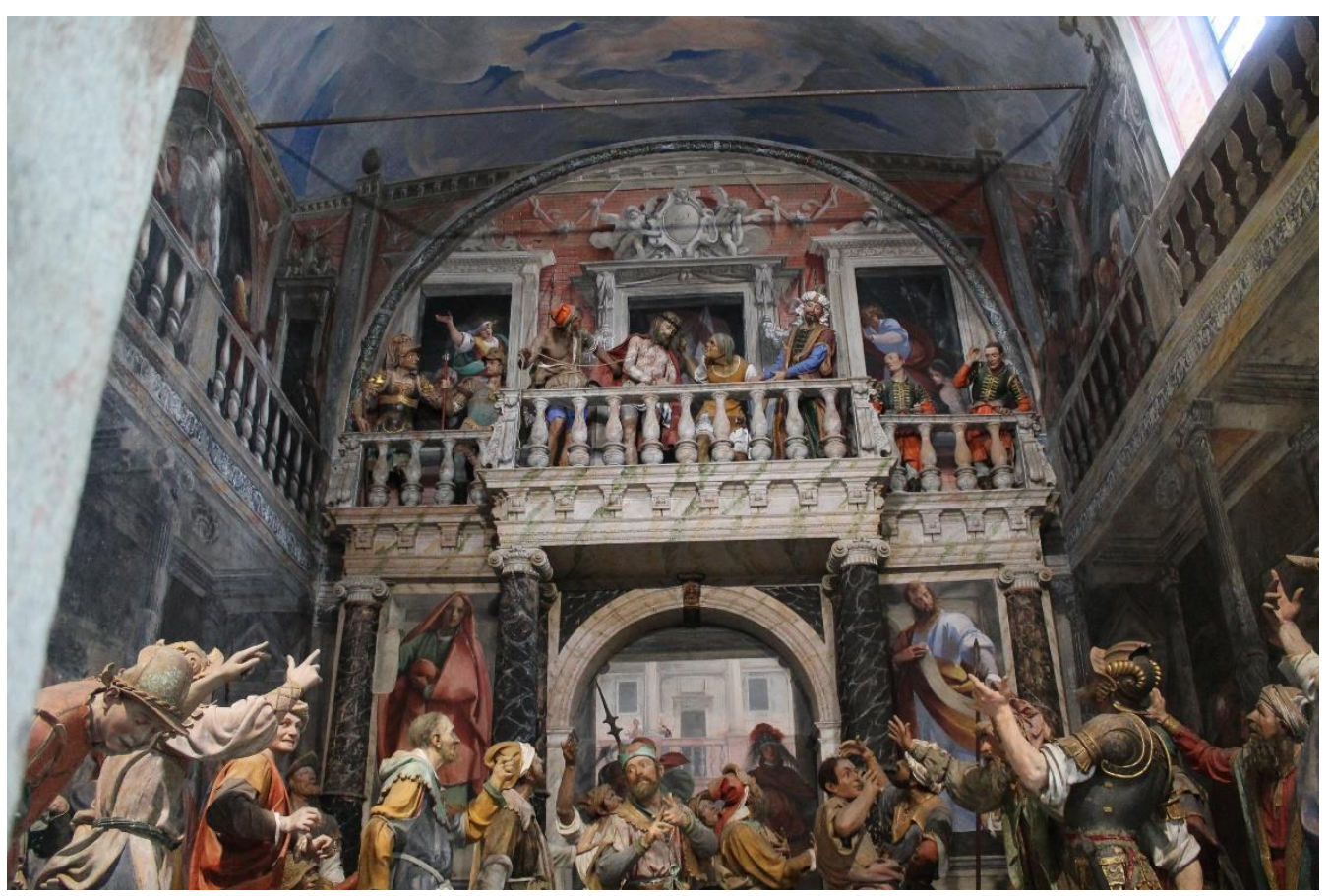

Figure 7: The interior of the Ecce Homo chapel at Varallo.

Photograph by author. 
Moreover, for the graffiti on the window panes of the Ecce Homo chapel the axiom 'the support is part of the message' may certainly hold true. ${ }^{60}$ The fact that these graffiti were made on the glass of the viewing screen of the Ecce Homo chapel can be further interpreted beyond its position as a devotional peak in the sacred topography of the sacro monte. These graffiti were written not just near or on the surface of the image but on the medium that transmits the image. So these graffiti exemplify and enshrine the act of looking at or meditating on the scene of Ecce Homo, thus recording the very act of 'beholding the man'. The eighteenth century visitors to the sacro monte who wrote their names on these panes left an enduring trace of their personalized and temporalized act of 'looking at'.

In addition these graffiti not only record a personal devotional experience, but they also have a social aspect. Apart from joining a community of fellow devotees who likewise left their mark at the Ecce Homo chapel, around half of these graffiti have to do with the strengthening of family ties. More than ten individuals with the family name Cantino joined this graffito family record over the years. ${ }^{61}$ For them making the pilgrimage to the sacro

[page 70]

monte constituted not only a visit to a sacred place, but also at the same time a significant joining of the ranks at a familial lieu de mémoire. Thus graffiti at the sacro monte of Varallo may serve as a source information about visitors, for example revealing their nationality, but they can also figure as witnesses to aid a reconstruction of what different points in the sacred itinerary of the sacro monte may have meant to devotees. Moreover, it is certainly possible to complicate the effectivity and impact of the 1594 ban on graffiti, which explicitly branded writing on windows as vandalism. The graffiti on the panes of the Ecce homo chapel alone demonstrate both the enduring presence and the significance of applying graffiti as a social and a devotional act at the sacro monte.

\section{Conclusion}

Based on the case of the sacro monte at Varallo, this article has sought to complicate the supposed pre-modern acceptance of graffiti, while at the same time assessing its continued significance in religious spaces after having been branded as illicit writing. In particular, it challenges the assumption that if graffiti are omnipresent at a site, they must have been generally accepted. Throughout its existence the sanctuary at Varallo has attracted many of these intentionally applied traces of personal presence and religious experience, even though 
explicitly forbidden from the late sixteenth century onwards. The 1594 ban on, and campaign against, graffiti launched by bishop Carlo Bascapè clearly defines applying graffiti as a punishable offence and vandalism. Bascapè also ordered his ban to be aggressively broadcast everywhere on sacro monte, hoping to eradicate graffiti entirely, also by ordering the removal of existing graffiti. Since institutional disapproval of graffiti at the sacro monte pre-dates Bascapè's campaign, and his prohibition seems to have been well received in the decades following its introduction, we may interpret it as representative of a more generally held attitude towards graffiti in Piedmont from the late sixteenth century onwards.

Graffiti at sacred sites were certainly not always met with disapproval everywhere in Western Europe during the medieval and early modern period. Examples of priests etching their names and other messages into church walls may illustrate this. However, it has been the purpose of this article to make clear that in order to assess the degree to which graffiti were accepted, it is vital to examine sources other than the graffiti themselves. Sources that represent institutionalized attitudes, such as Bascapè's ban on graffiti, are particularly helpful. This may help to avoid an equation between the overwhelming presence of graffiti at certain sites and general or institutional acceptance. Even if graffiti were not allowed or appreciated, this may have been generally ignored by graffitists. For example, graffiti at the Ecce Homo chapel and elsewhere at the sacro monte of Varallo demonstrate that the actual long term effectiveness of the 1594 ban was quite limited. At the chapel of the Temptation, the same is illustrated by the nineteenth-century frame painted around the fresco of the original ban, made in order to reinforce it visually.

Moreover, consideration of the graffiti at the Ecce Homo chapel also demon-

[page 71]

strates the enduring significance of graffiti at this sanctuary even after the introduction of the ban. Visitors do not seem to have been particularly deterred by it, still feeling inspired to leave a mark of personal engagement with the passion at this devotional peak in the parcours of the sacro monte. What is more, these traces illustrate the significance of graffiti as a subscription to a particular social group, even beyond a religious community, as the graffiti record of visitors belonging to the Cantino family illustrates. Graffiti can thus figure as an important source for historical research, offering not only information about the kind of visitors it attracted, but also about what the sacro monte meant to them. All in all, the case study of graffiti and its reception at the sacro monte of Varallo demonstrates that the relationship between graffiti, its functions at sacred sites, and institutional acceptance or disapproval need by no means be one- 
dimensional. We should therefore avoid to make arguments from silence, and begin to document the historical reception of graffiti, either positive or negative, alongside the monumental task of gathering representative corpora of graffiti for the medieval and early modern period.

\begin{abstract}
About the author
Dr. Marianne Ritsema van Eck is a specialist in religious history and material culture during the late medieval and early modern period. She obtained her doctorate in medieval history at the University of Amsterdam (UvA), and is currently assistant professor in medieval history at Leiden University.

E-mail: m.p.ritsema.van.eck@hum.leidenuniv.nl
\end{abstract}

[page 72]

\title{
Appendix: Graffiti on windowpanes of Ecce Homo chapel (chapel no. 33) at the sacro monte of Varallo.
}

Legenda: " indicates what is written on a single glass pane; / indicates that what follows is written on the next 'line'; [ ] indicates editorial suggestions or additions; [?] indicates illegible letters or words; [word/letter ?] when transcription is uncertain; (ad) is the abbreviation sign @ written out.

On the leftmost section, from left to right:

1. "io Giuseppe Cantino / [?]"

2. "Danielo Cantino con suo fratelo Santino Cantino"

3. "Danielo Cantino / ... / Go[r?]ge mone[?]o 1601"

4. "1733 / 173[?] [?] 13 magio / io giovan br[?]sia / Bonai[?]co sua molie / barbo[r]a [?] [?]"

5. "1773 (ad) 3 / magio / gian Antonio Cantino con conpagni / oi [agostino? [or] ugolino?]"

6. "1730 [?] 3 giugnio / Carlo Bonazola con / sua mulie maria / antonia bonazola / [?]"

7. "177[3/5?] Ba[?] Cantino / con sua [?] [?] / con [?] ant[?]no cantino."

8. "Fortuna cantino con / suo figlio Tomaso 1778 / (ad) 8 genaio"

9. "1750"

10. "Antoine Faglietti 1991"

11. "[Gaomo?] / Magio / 1779 / m[?]osa" 
Panes middle section:

12. "1730 (ad) 16 Aprile [?] / Antonio Cantino / 1738 [?] primo Aprile / io giusepe arnoldo luito Capo [?]"

Panes of the rightmost section, from left to right:

13. "Joseph Borolz 1568 [scratced out] / G.A.C.F. / di liulio 1744"

14. "1719 (ad) 29 Ago. / Tomaso de Angeli"

15. "io gacomo arnoldo / [Alfa?]"

16. "Bruni / Bruni 18[?]8"

17. "G. Pirrotus"

18. "Me[r?]lo [et?] / guilo [cantino?] figlio"

19. "Baser [?] Caval"

\footnotetext{
${ }^{1}$ Samuel Butler, Alps and sanctuaries of Piedmont and the canton Ticino (London 1882) 304-305; for a characterization of Butler's work see, Clarice Zdanski, 'Samuel Butler, local identity, and the periodization of Northern Italian art: the travel writer-painter's view of art history' in: James G. Paradis ed. Samuel Butler: Victorian against the grain, a critical overview (Toronto 2007) 223-250. esp. 231; Butler published a dedicated monograph on the sanctuary at Varallo: Samuel Butler, Ex voto: An account of the Sacro Monte or New Jerusalem at Varallo-Sesia (London 1888).

2 Juliet Fleming, 'Wounded walls: graffiti, grammatology, and the age of Shakespeare', Criticism 39.1 (1997) 1 30, esp. 4-5; this essay has recently been republished in amended form in: Juliet Fleming, Graffiti and the writing arts of Early Modern England (London 2001) 29-72.

${ }^{3}$ Fleming, 'Wounded walls', 4.

${ }^{4}$ Please see below in the following section, or visit the project website, http://www.medieval-graffiti.co.uk/ ${ }^{5}$ Véronique Plesch, 'Memory on the wall: graffiti on religious wall paintings', Journal of Medieval and Early Modern Studies 32.1 (2002) 167-198, esp. 168.

${ }^{6}$ Binsfeld provides an overview of graffiti in religious spaces during this period ranging from Italy, Asia Minor, Syria, the Holy Land, Egypt, to France, and also includes pagan sanctuaries. Andrea Binsfeld, Vivas in deo: die Graffiti der frühchristlichen Kirchenanlage in Trier (Trier 2006) 43-148.

${ }^{7}$ Ann Marie Yasin, 'Prayers on site: the materiality of devotional graffiti and the production of early Christian sacred space' in: Antony Eastmond ed. Viewing inscriptions in the late antique and medieval world (Cambridge 2015) 36-60, esp. 41-44; Plesch, 'Memory on the wall', 169.

${ }^{8}$ Yasin, 'Prayers on site', 44-47.

${ }^{9}$ Véronique Plesch, 'Destruction or preservation? The meaning of graffiti on paintings in religious sites' in: Virginia Chieffo Raguin ed. Art, piety, and destruction in the Christian West, 1500-1700 (Farnham 2010) $137-$ 172, esp. 147.

${ }^{10}$ For example, important work has been done on medieval graffiti in France as well: Asger Jorn and P.V. Glob, Signes gravés sur les églises de l'Eure et du Calvados (Borgen 1964); Alain Joubert, Bateaux votifs des églises du Val de Seine: exposition d'ex-votos et graffiti marins (Quillebeuf 1977).

${ }^{11}$ V. Pritchard, English medieval graffiti (Cambridge 1967).

${ }^{12}$ For a bibliography see the website of the Norfolk Medieval Graffiti Survey: http://www.medievalgraffiti.co.uk/

${ }^{13}$ Matthew Champion, Medieval graffiti: the lost voices of England's churches (London 2015) 5.

${ }^{14}$ Fleming, 'Wounded walls', 2.

${ }_{15}$ Martin Blindheim, Graffiti in Norwegian stave churches, c. 1150-c.1350 (Oslo 1985).

${ }^{16}$ Ibidem, 11-12.
} 
${ }^{17}$ Ibidem, 27-30.

${ }^{18}$ Ibidem, 13-16.

${ }^{19}$ Annette Jones, 'Portals to the past: distribution in stave church inscriptions' in: Preprints to The 7th

International Symposium on Runes and Runic Inscriptions (Oslo 2010) 7.

${ }^{20}$ Jones, 'Portals to the past', 3-7.

${ }^{21}$ Macody Lund, 'En Nidindskrift på Kathedralen i Nidaros -af historisk interesse', Historisk Tidsskrift 30

(1934-36) 353-373, esp. 358; I thank Rolv Nøtvik Jakobsen and Heidi Anett Øvergård Beistad for drawing my attention to this graffito.

${ }^{22}$ I thank Jacobine Gelderloos-Commandeur for bringing this to my attention. '[...] Sal ook nijemant hem vervorderen met crijt houtkool ofte/ ander materijalen te schrijven an enige mueren ofte colommen binnen/ de kercken deser stede noch inde bancken ofte houtwerck te sniden op pene/ [...]' Jacobine Gelderloos, Het kerkgebouw als publieke ruimte in de Nederlandse Republiek, MA thesis University of Groningen (2012) Appendix no. 69.

23 'Niemand, [...], mag [...], krijten, [...] in de kerk, in het portaal of buiten de kerk, hetzij onder tijd of dienst van predikatie, catechisatie (ervoor of erna), [...]. Op boete van 20 stuivers [...]. Het is verboden in de kerk te snijden aan het koor, preekstoel, pilaren, deuren, banken of enig ander hout-werk, [...]' Gelderloos, Het kerkgebouw, Appendix no. 73.

${ }^{24}$ Maps and plans of the current layout of the sanctuary may easily be found via online web search engines. Marianne Ritsema van Eck, Custodians of sacred space: constructing the Franciscan Holy Land through texts and sacri monti (ca. 1480-1650), PhD diss. University of Amsterdam (2017), 214-8.

${ }^{25}$ Yasin offers various examples of early Christian graffiti on the Italian peninsula, as well as references to academic works documenting them. Yasin, 'Prayers on site', 36-60; medieval religious graffiti on the Italian peninsula have received less attention in comparison. However, important headway has been made towards remedying this situation by Mia Trentin, whose doctoral dissertation documents and studies graffiti in churches along important Italian pilgrimage routes, from the ninth to the end of twelfth century. Mia Trentin, I graffiti come fonte per la storia delle pratiche religiose medievali, Phd diss. Universitá Ca'Foscari Venezia (20102011).

${ }^{26}$ Plesch, 'Memory on the wall', 178-181.

${ }^{27}$ Plesch, 'Destruction or preservation?', 142.

${ }^{28}$ Guido Gentile, 'Sulle tracce degli antichi visitatori: percorsi e graffiti' in: Elena de Filippis ed., Gaudenzio Ferrari: la crocifissione del Sacro Monte di Varallo (Turin 2006) 65-73.

${ }^{29}$ De Filippis ed., Gaudenzio Ferrari: la crocifissione.

${ }^{30}$ Yasin, 'Prayers on site', 41-44; Plesch, 'Memory on the wall', 169.

${ }^{31}$ Gentile, 'Sulle tracce', 70-73.

${ }^{32}$ Ibidem, 73.

${ }^{33}$ Pier Giorgio Longo, 'Il sacro monte di Varallo nella seconda metà del XVI secolo' in: Da Carlo Borromeo a Carlo Bascapè (Novara 1985) 83-182.

${ }^{34}$ Pier Giorgio Longo, '«Un luogo sacro... quasi senz' anima» Carlo Bascapè e il sacro monte di Varallo.' in: Carlo Bascapè sulle orme del Borromeo (Novara 1994) 369-426; Guido Gentile, 'Gli interventi di Carlo Bascapè nella regia del Sacro Monte di Varallo' in: Carlo Bascapè sulle orme del Borromeo (Novara 1994) 427-490, esp. 432-9.

${ }^{35}$ Gentile, 'Gli interventi', 439-444, 477-482.

36 'Inscriptiones quae in parietibus seu cancellis, germanico, gallico, aliove caractere notatae sunt, deleantur, nec inscribi de coetero permitantur.' Longo, 'Il sacro monte', 173 (Decrees pastoral visit Cesare Speciano, September 1585).

37 'Per ordine di Monsignor Reverendissimo vescovo di Novara, fatto a 26 di Settembre 1594: Niuno ardisca scrivere sopra muri, imagini, cancelli, porte, vetriate, colonne, o altro delle capelle di questo sacro monte né altrimente guastarle sotto pena dell'interdetto della chiesa da incorrersi ipso facto, senz'altro, et di quattro scudi la metà alla fabrica et. l'altra metà all'accusatore.' Gentile, 'Gli interventi', 482-3, cf. 444-5.

${ }^{38}$ Gentile, 'Gli interventi', 482-3, cf. 444-5; on restoring away graffiti, see Plesch, 'Destruction or preservation?', 143.

${ }^{39}$ Yasin, 'Prayers on site', 49.

${ }^{40}$ Christine Göttler, 'The Temptation of the Senses at the Sacro Monte di Varallo' in: Wietse de Boer and Christine Göttler ed., Religion and the senses in early modern Europe (Leiden 2013) 393-451, esp. 430-431.

${ }^{41}$ Graffiti tend to attract more graffiti, cf. Yasin, 'Prayers on site', 40.

${ }^{42}$ Guido Gentile, '1507. Una comitiva di pellegrini francesi al Sepolcro di Varallo', Novarien 30 (2001) 241248.

${ }^{43}$ Plesch, 'Destruction or preservation?', 142.

${ }^{44}$ The word accusatore, accuser, is scratched out on the fresco of the ban in the chapel of the Temptation, suggesting popular dissatisfaction with the ban. 
45 'D'ordine ancora dell'Eccell. Senato di Milano fatto sotto li 24. di Maggio 1595. \& sottoscritto dall'Egr. Secretario Marchisonio, uscì il seguente Decreto. S'auvisa qualunque persona, che non ardisca scrivere, nè far alcuna macchia sopra Muri, Porte, nè altra cosa delle Capelle di questo Sacro Monte con Carbone, ò altra materia, sotto pena di Scudi 25. d'Oro e di due tratti di Corda; e che in alcun modo non ardisca scrivere sopra Imagini d'esso Sacro Luogo, nè in qualunque modo macchiarle, sotto pena di Scudi 50 d'Oro, e di trè tratti di corda.' Pietro Antonio Ribetti di Venezia, Giardino Serafico Istorico (Venice 1710) 389.

46 'Contro à quelli, che scrivono sopra le candide mura delle Cappelle / Qui polluerit illud, morte morietur. Exodi 21 / Ah folle, temeraria, e ardita mano, / Che tinger osi con vana scrittura / Le sacre mura del Monte sovrano. / Sentirai doppia pena grave, e dura, / Essendo colto all'improviso ò vano: / Ogni fio pagherai di tua lordura. / Il Turco istesso ti confonda in questo, / Ch'in suo Tempio non sputa: empio nel resto.' Bartolomeo Manino, Descrittione de sacri monti di S. Carlo d'Arona, di S. Francesco d'Horta sopra Varese e di Varallo (Milan 1628) 16.

47 'Il vescovo Don Carlo stabilite le cose in questo modo venne alla visita li 5.d'Ottobre. Diede fuori ordini rigorosi questo prelato di censure, scommuniche, ed altre pene pecuniarie contro quelli che dipingeranno, romperanno, macchiaranno, sporcaranno con caratteri, nomi, carboni, ed altro le pitture, statue, vetriate, muri, ò altro del sacro monte, solendo molti idioti scrivere simili materi sopra muri, ed altro. [margins: Don Carlo Basgapè in visita da alcuni ordini. Confirma alcuni altri decreti del 1594.]' Giovanni Battista Fassola, La nuova Gierusalemme o sia il santo Sepolcro di Varallo (Milan 1671) 42-43.

${ }^{48}$ Longo, 'Il sacro monte', 87-88.

${ }^{49}$ See above.

${ }^{50}$ Plesch, 'Destruction or preservation?', 142.

${ }^{51}$ Ibidem, 147-160.

${ }^{52}$ Appendix no. 14; see appendix for the other graffiti as well.

${ }^{53}$ The two earliest years mentioned suggest that the glass panes were reused form another chapel, during the construction of the present Ecce Homo chapel from 1602 onwards. The first 'Joseph Borolz 1568' has been scratched out, possibly suggesting an attempt to cancel the graffito during construction of the viewing screen. nos. 3, 10, 13, and 16; nos. 17, 19 appear modern too, but are undated.

${ }^{54}$ Elizabethan England knew diamond rings specifically designed for writing on windows, so-called 'writing rings'. Fleming, 'Wounded walls', 13.

${ }^{55}$ Appendix no. 6.

${ }^{56}$ Appendix no. 8.

${ }^{57}$ Plesch, 'Memory on the wall', 168; Yasin, 'Prayers on site', 52.

${ }^{58}$ Gentile, 'Gli interventi', 455-457, 486-487.

${ }^{59}$ Ibidem, 459-460, 490.

60 '..., the support is part of the message: the surface that receives the graffiti must be considered, in order to fully understand its message.' Plesch, 'Destruction or preservation?', 153.

${ }^{61}$ On the panes of the screen of the next chapel (Pilate washing his hands in innocence), two more graffiti by Cantino's are found: "1785/ Antonio Cantino / Cantino [?]", "SANTINO / CANTINO". 